\title{
Statins Accelerated Arthritic Incidence: Ex vivo Antioxidant and Histopathological Analysis
}

\author{
Litty Joseph ${ }^{1}$, Jithin Mathew*2 \\ ${ }^{1}$ Division of Pharmacology, Department of Pharmaceutical sciences, Centre for \\ Professional and Advanced studies (CPAS), Cheruvandoor campus, Ettumanoor- \\ 686631, Kottayam, Kerala, India. \\ ${ }^{2}$ Department of Pharmacology, Nehru College of Pharmacy, Pampadi, \\ Thiruvilwamala- 68058, Thrissur, Kerala, India. \\ littyjimmyalappatt@gmail.com, 2jithinmathew051@gmail.com
}

\begin{abstract}
Corresponding Author*
Mr. Jithin Mathew, M.Pharm.,

Assistant Professor

Department of Pharmacology

Nehru college of Pharmacy, Pampadi,

Thiruvilwamala-68058, Kerala, India.
\end{abstract}




\begin{abstract}
Statins are conventionally used medicaments for the treatment of hyperlipidemia and hypertension. Apart from the aforementioned pharmacological action, statin use was associated with increased risk for developing rheumatoid arthritis due to its immunomodulatory property. The present study focused to demonstrate whether statin use accelerated arthritic incidence.The Ex vivo antioxidant study was performed using Lipid peroxidation (LPO) and Superoxide dismutase (SOD) activity assay. Both the Antioxidant study was evaluated from tissue homogenates. Each homogenate was centrifuged, and the resulting supernatant fraction was used to determine the enzyme activity. The histopathological analysis of ankle joints was conducted by hematoxylin eosin staining technique. The result obtained from Lipid peroxidation study showed that both Pitavastatin and Lovastatin treated tissues exhibited significant increase $(p<0.001)$ in enzyme activity due to the elevated level of malonaldehyde formation. The Superoxide dismutase activity assay of both test drugs on tissue homogenate was found that significant decrease $(p<0.001)$ in SOD level contributed cartilage degradation due to the generation of free radicals. The histopathological analysis also revealed that scattered inflammatory cells destructs the normal articular structure in rat joint tissues showed the evidence of arthritic induction. The study confirmed that statins had a strong influence on arthritic onset by oxidative stress in patients with hyperlipidemia and hypertension.
\end{abstract}

Keywords: Rheumatoid arthritis; Antioxidant; Pitavastatin; Oxidative stress; Superoxide dismutase; Lipid peroxidase. 


\section{Introduction}

Rheumatoid arthritis (RA) is an autoimmune disease marked by nonspecific swelling of peripheral joints, degeneration of joints and damage of articular tissues. If the disease becomes severe, there may be higher risk for bone damage and destruction of cartilages [1,2]. The clinical manifestations of rheumatoid arthritis is characterized as arthralgia, swelling, redness, and even limiting the range of motion $[3,4]$.The recent studies are showed that this disease can occur at any age, with increasing prevalence up to seventh decade of life. The disease is three times more common in adult females [5].

Apart from the traditional use of statins, these compounds have inflammatory and immunomodulatory properties [6]. An observational study conducted on the use of statins revealed that these compounds having both lipoprotein improvement and arthritic potential, it might be expected to confer an accelerated arthritic onset in patients with rheumatoid arthritis [7]. In line with this hypothesis, it clearly exhibited that statin use was associated with an increased risk of developing rheumatoid arthritis (RA) [8].

The present study was conducted by using ex vivo antioxidant studies such as, lipid peroxidation and superoxide dismutase activity and histopathological analysis. The enzyme lipid peroxidase having significant role in inflammatory reactions. The lipid peroxidation is the method indicated that disorganization of cell structure including lipids, membranes, proteins and DNA, Malonaldehyde (MDA) is the end product released by the peroxidation reaction, which act as a key indicator in arthritic incidence [9].The enzyme Superoxide dismutase enhances the conversion of superoxide anion to molecular oxygen and hydrogen peroxide ,thus decreased expression of aforementioned enzyme may reduce the action of collagenase, which contributes to cartilage degradation[10]. The study elicited that statins had a crucial role in the development of rheumatoid arthritis.

\section{Materials and Methods}

\subsection{Animals}

Female albino wistar rats weighing 150- 200g were procured from the small animals breeding station, Mannuthy, Kerala, India. They were housed in polypropylene cages under standard environmental condition (12hr dark/ 12 hour light cycle: temperature, $25 \pm 2^{\circ} \mathrm{C}, 35-60 \%$ humidity, air ventilation) and were fed with standard diet (VRK nutritional solutions, Maharashtra, India) and water ad libitum. The animals were acclimatized to the environment for 2 weeks prior to experiment use. All the animal experiments were done after getting the approval from the institutional animal ethical committee (IAEC/M.Pharm/DPS/2018-19).

\subsection{Lipid Peroxidation study}

Excised the rat joint tissues from following groups such as control, Arthritic control, Pitavastatin and Lovastatin before collagen induced arthritis group (CIA) and Pitavastatin and Lovastatin after collagen induced arthritis group (CIA). The tissues washed with cold saline, blotted dry and weighed. A $10 \%(\mathrm{w} / \mathrm{v})$ homogenate was prepared by using $10 \mathrm{mM}$ potassium phosphate buffer $\mathrm{p}^{\mathrm{H}} 7.4$ containing $30 \mathrm{mM}$ 
Potassium chloride and centrifuged at $1000 \mathrm{~g}$ for 10 minutes to remove cell debris and nuclei. The resultant supernatant were stored at $-80^{\circ} \mathrm{C}$ and carried out centrifugation at $4^{\circ} \mathrm{C}$. In the assay, the final reaction mixture was heated in boiling water bath at $80^{\circ} \mathrm{C}$ for 60 minutes and cooled. The contents were centrifuged at $4000 \mathrm{rpm}$ for 5 minutes at $4^{\circ} \mathrm{C}$. Finally, the absorbance's measured at $532 \mathrm{~nm}$ using UV Visible spectrophotometer [11].

\section{Calculation}

The following formula was utilized to calculate the lipid peroxidation activity

Nano moles/gm of MDA $=\underline{3 x \Delta O D}$

$$
0.152
$$

Where total volume is given as $3 \mathrm{ml}$,

$0.152=$ It is the optical density of MDA at $532 \mathrm{~nm}$

$\Delta \mathrm{OD}=$ Change in optical density

\subsection{Superoxide Dismutase Activity}

Homogenate of the rat joint tissues were prepared, and each homogenate was centrifuged for $30 \mathrm{~min}$ at $800 \mathrm{~g}$, the resulting supernatant fraction was used to determine the enzyme activity $.50 \mathrm{ml}$ of the homogenate was added to the mixture of $2.8 \mathrm{ml}$ tris-EDTA and $100 \mathrm{ml}$ of $2 \mathrm{mM}$ pyrogallol at $25^{\circ} \mathrm{C}$. The optical density of the mixture was read at zero and three minutes at $420 \mathrm{~nm}$ [12].

\section{Calculation}

The Superoxide dismutase activity was determined by using the given equation

Activity $(\mathrm{U} / \mathrm{mg})=\underline{(\Delta \mathrm{OD} \text { reference }-\Delta \mathrm{OD} \text { sample }) \text { Total volume }}$

$$
\Delta \mathrm{OD} \text { of reference } \mathrm{x} \text { Sample volume }
$$

Where, $\Delta \mathrm{OD}=$ Change in optical density

\subsection{Histopathological Analysis}

Ankle joints were separated from the hind paw and immersed in $10 \%$ buffered formalin for 24 hours followed by decalcification in 5\% formic acid, processed for paraffin embedding sections at $5 \mu$ thickness. The sections were stained with haematoxylin-eosin and evaluated under light microscope with $10 \mathrm{X}$ magnifications for the presence of inflammatory cells, hyperplasia of synovium, pannus formation and destruction of joint space.

\subsection{Statistical Analysis}

Statistical comparison and significance were analyzed by one-way ANOVA followed by Turkeys post hoc multiple comparison test using Graph pad prism 6.00 version. Results were expressed as mean \pm SEM ( $n=6$ rat per group). Values of $p<$ $0.05, \mathrm{p}<0.01$ and $\mathrm{p}<0.001$ were indicative of statistically significant differences

\section{Result and Discussion}




\subsection{Lipid Peroxidation}

The present study exhibited that there was significant increase $(\mathrm{p}<0.001)$ in malonaldehyde level in arthritic control group $(8.56 \pm 0.058)$ as compared to normal control group. However, data suggested that Pitavastatin $(15.32 \pm 0.1045)$ and Lovastatin (15.46 \pm 0.09877) after collagen induced arthritic group (CIA) showed significant rise $(\mathrm{p}<0.001)$ in free radical generation, when compared with Pitavastatin (13.44 \pm 0.04698$)$ and Lovastatin (13.25 \pm 0.1020$)$ before collagen induced arthritic group, arthritic control group and normal control group. Anyhow, based on the result obtained from the current study elicited that Lovastatin and Pitavastatin after CIA induction had a strong influence on free radical mediated cellular damage through activation of lipid peroxidase level, which brought cartilage degradation.

\section{Table 1. Effect of Pitavastatin and Lovastatin on Lipid peroxidation in Collagen Induced Arthritic Rat Model.}

\begin{tabular}{|c|c|c|}
\hline SL NO. & GROUPS & LPO $(\mathbf{n m o l} / \mathbf{m g}$ of protein) \\
\hline 1 & Normal control & $5.46 \pm 0.00178$ \\
\hline 2 & Arthritic control Group & $8.56 \pm 0.05777^{\mathrm{c}}$ \\
\hline 3 & $\begin{array}{c}\text { Pitavastatin before CIA } \\
\text { Induction. }\end{array}$ & $13.44 \pm 0.04698^{\mathrm{cgu}}$ \\
\hline 4 & $\begin{array}{c}\text { Pitavastatin after CIA } \\
\text { Induction. }\end{array}$ & $15.32 \pm 0.1045^{\mathrm{cgr}}$ \\
\hline 5 & $\begin{array}{c}\text { Lovastatin before CIA } \\
\text { Induction. }\end{array}$ & $13.25 \pm 0.1020^{\mathrm{cg}}$ \\
\hline 6 & $\begin{array}{c}\text { Lovastatin after CIA } \\
\text { Induction. }\end{array}$ & $15.46 \pm 0.09877^{\mathrm{cgr}}$ \\
\hline
\end{tabular}

Values were expressed as Mean \pm SEM, $(n=6)$. Data were analyzed by one-way ANOVA followed by multiple comparison Turkeys post hoc test. ${ }^{a} \mathrm{p}<0.05,{ }^{b} \mathrm{p}<0.01$, ${ }^{c} \mathrm{p}<0.001$ when compared with normal; ${ }^{\mathrm{e}} \mathrm{p}<0.05,{ }^{\mathrm{p}} \mathrm{p}<0.01,{ }^{\mathrm{g}} \mathrm{p}<0.001$ when compared with positive control; ${ }^{\mathrm{p}} \mathrm{p}<0.05,{ }^{\mathrm{q}} \mathrm{p}<0.01,{ }^{\mathrm{r}} \mathrm{p}<0.001$ when compared with Lovastatin before CIA induction; ${ }^{\mathrm{s}} \mathrm{p}<0.05,{ }^{\mathrm{t}} \mathrm{p}<0.01$, ${ }^{\mathrm{p}} \mathrm{p}<0.001$ when compared with Lovastatin after CIA induction.

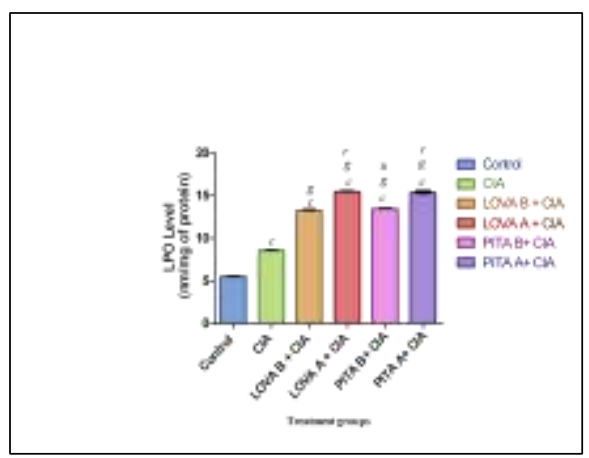


Figure 1. Effect of Pitavastatin and Lovastatin on Lipid peroxidation in Collagen Induced Arthritic Rat Model.

Values were expressed as Mean \pm SEM, $(n=6)$. Data were analyzed by one-way ANOVA followed by multiple comparison Turkeys post hoc test. ${ }^{a} p<0.05,{ }^{b} p<0.01$, ${ }^{c} p<0.001$ when compared with normal; ${ }^{e} p<0.05,{ }^{\mathrm{f}} \mathrm{p}<0.01,{ }^{\mathrm{g}} \mathrm{p}<0.001$ when compared with positive control; ${ }^{\mathrm{p}} \mathrm{p}<0.05,{ }^{\mathrm{q}} \mathrm{p}<0.01,{ }^{\mathrm{r}} \mathrm{p}<0.001$ when compared with Lovastatin before CIA induction; ${ }^{\mathrm{s}} \mathrm{p}<0.05,{ }^{\mathrm{t}} \mathrm{p}<0.01,{ }^{\mathrm{u}} \mathrm{p}<0.001$ when compared with Lovastatin after CIA induction.

\subsection{Superoxide Dismutase Activity}

The production of oxygen free radicals that occurs with the development of arthritis due to decreased Superoxide dismutase levels as consequences of their consumption during oxidative stress and cellular lysis. Superoxide dismutase plays an important role in the detoxification of superoxide anion there by protecting the cells against oxidative free radicals induced damage. The present study investigated that Pitavastatin $(6.44 \pm 0.1233)$ and Lovastatin $(6.38 \pm 0.0655)$ after CIA induction showed significant decrease $(\mathrm{p}<0.001)$ in superoxide dismutase level when compared to Pitavastatin $(10.20 \pm 0.1925)$ and Lovastatin $(10.31 \pm 0.0464)$ before CIA induction group. However, the study concluded that based on the data from Table No: 2 revealed that Lovastatin and Pitavastatin after CIA induction exhibited least enzyme activity. The study confirmed that both the aforementioned test drugs after CIA induction promoted cartilage degradation in given joint tissues due to the generation of more number of free radicals by the process of oxidative stress.

\section{Table 2. Effect of Pitavastatin and Lovastatin on Superoxide dismutase} Activity in Collagen Induced Arthritic Rat Model.

\begin{tabular}{|l|l|l|}
\hline SI.NO. & GROUPS & SOD (U/mg of protein) \\
\hline 1 & Normal control & $8.37 \pm 0.04688$ \\
\hline 2 & $\begin{array}{c}\text { Arthritic control } \\
\text { Group }\end{array}$ & $13.45 \pm 0.0965^{\mathrm{c}}$ \\
\hline 3 & $\begin{array}{c}\text { Pitavastatin before } \\
\text { CIA Induction }\end{array}$ & $10.20 \pm 0.1925^{\mathrm{cgu}}$ \\
\hline 5 & $\begin{array}{c}\text { Pitavastatin after } \\
\text { CIA Induction. }\end{array}$ & $6.44 \pm 0.1233^{\mathrm{cgr}}$ \\
\hline 6 & $\begin{array}{c}\text { Lovastatin before } \\
\text { CIA Induction. }\end{array}$ & $10.31 \pm 0.0464^{\mathrm{cg}}$ \\
\hline & $\begin{array}{c}\text { Lovastatin after CIA } \\
\text { Induction. }\end{array}$ & $6.38 \pm 0.0656^{\mathrm{cgr}}$ \\
\hline
\end{tabular}

Values were expressed as Mean \pm SEM, $(n=6)$. Data were analyzed by one-way ANOVA followed by multiple comparison Turkeys post hoc test. ${ }^{\mathrm{a}} \mathrm{pe}<0.05$, ${ }^{\mathrm{b}} \mathrm{p}<$ $0.01,{ }^{c} p<0.001$ when compared with normal; ${ }^{u} p<0.05,{ }^{f}$ op $<0.01,{ }^{g} p<0.001$ when compared with positive control; ${ }^{\mathrm{p}} \mathrm{p}<0.05,{ }^{\mathrm{q}} \mathrm{p}<0.01,{ }^{\mathrm{r}} \mathrm{p}<0.001$ when compared with Lovastatin before CIA induction; ${ }^{\mathrm{s}} \mathrm{p}<0.05,{ }^{\mathrm{t}} \mathrm{p}<0.01$, $\mathrm{p} \mathrm{p}<0.001$ when compared with Lovastatin after CIA induction 


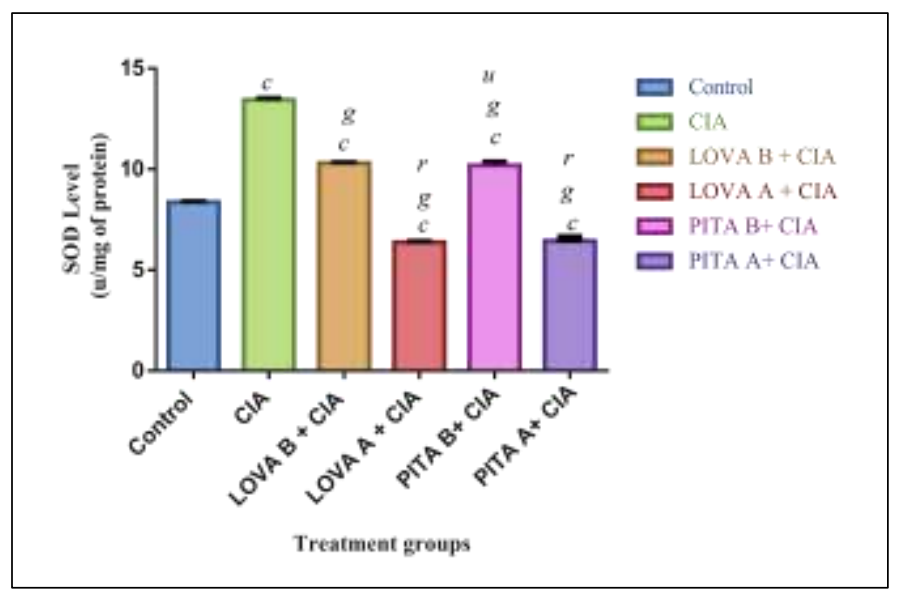

Figure 2. Effect of Pitavastatin and Lovastatin on superoxide dismutase activity in collagen induced arthritic rat model.

Values were expressed as Mean \pm SEM, $(n=6)$. Data were analyzed by one-way ANOVA followed by multiple comparison Turkey ${ }^{\text {'s }}$ post hoc test. ${ }^{a} \mathrm{p}<0.05,{ }^{b} \mathrm{p}<0.01$, ${ }^{c} \mathrm{p}<0.001$ when compared with normal; ${ }^{\mathrm{u}} \mathrm{p}<0.05,{ }^{\mathrm{f}} \mathrm{op}<0.01,{ }^{\mathrm{g}} \mathrm{p}<0.001$ when compared with positive control; ${ }^{\mathrm{p}} \mathrm{p} .<0.05,{ }_{\mathrm{i}}<0.01,{ }^{\mathrm{r}} \mathrm{p}<0.001$ when compared with Lovastatin before CIA induction; ${ }^{\mathrm{s}} \mathrm{pa}<0.05$, ${ }^{\mathrm{t}} \mathrm{p}<0.01$, $\mathrm{p}<0.001$ when compared with Lovastatin after CIA induction.

\subsection{Histopathological Analysis}

The histology report showed that the joint of paw in normal control rats had shown intact articular cartilage and normal joint space without inflammation. Section revealed that bony tissue with normal bony trabecular and skin appendages were normal. The section found in arthritic control group had normal bony tissue while narrowing of joint space and synovial tissue showed dense inflammation. The excised joint tissues of both Pitavastatin and Lovastatin before CIA induction exhibited that scattered inflammatory cells were destruct the normal articular structure and possess narrowed joint space. The report suggested that the tissues brought from after CIA induction elicited that joint space gets narrowed due to the presence of infiltrated cells. The blood vessels were appeared congested and scattered inflammatory cells were surrounding it. It confirmed that severe inflammation. 

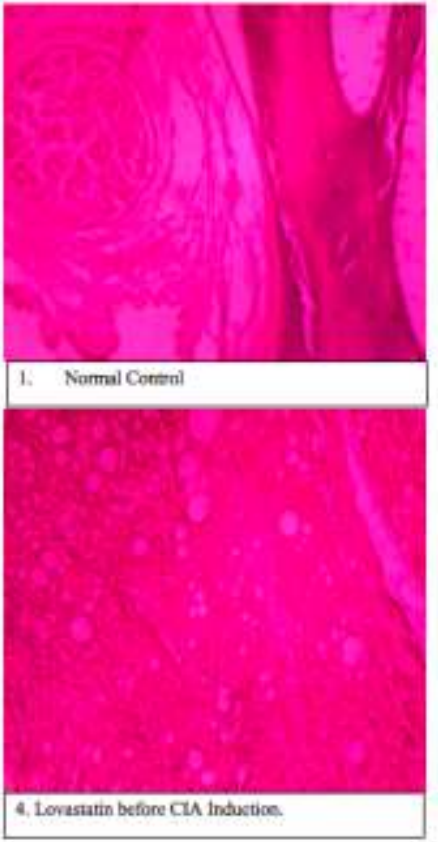

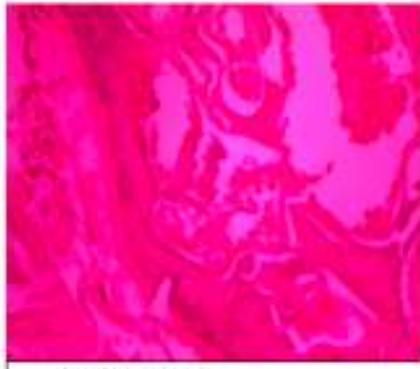

2. Artritic Centul

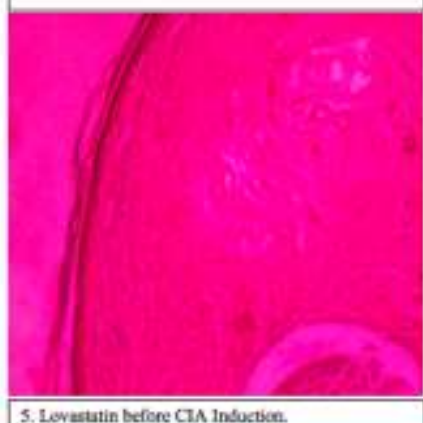

5. Levastatin before C1A Infuction.

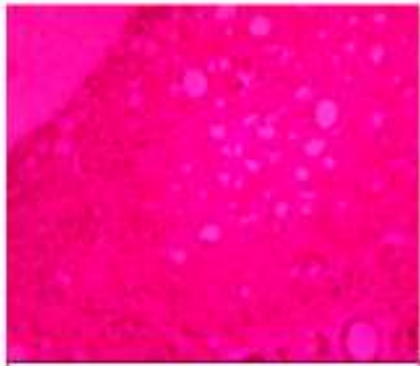

3. Pitavasario before CLA lufuetion.

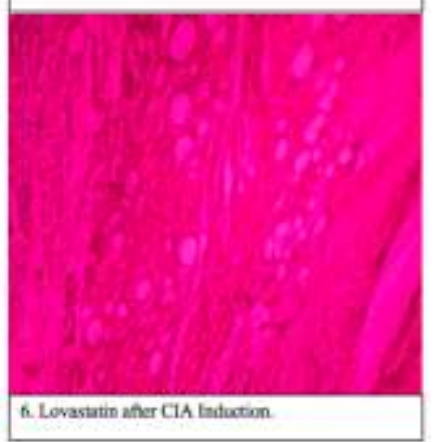

\section{Figure 3. Effect of Pitavastatin and Lovastatin on Histopathological Analysis on Collagen Induced Arthritic Rat Model}

\section{Conclusion}

The study was aimed at revealing the accelerated arthritic incidence of Pitavastatin and Lovastatin. The enzyme lipid peroxidase may have a role in pathogenesis of rheumatoid arthritis. In the present study both test drugs significantly increased the aforementioned enzyme activity in rat joint tissues indicated the cell damage by the activation of oxidative stress. The work was designed to determine the decreased expression of superoxide dismutase activity due to increased level of free radical formation, which in turn contributed cartilage degradation. In overall, the statin use was associated with increased risk for developing rheumatoid arthritis.

\section{Acknowledgment}

The authors are thankful to Prof. Dr. Jyoti Harindran, Principal, Department of Pharmaceutical sciences, Centre for professional and advanced studies (CPAS), Cheruvandoor, for providing infrastructural support.

\section{References}

[1] Majitha V and Geraci SA, "Rheumatoid Athritis: Diagnosis and Managemen", American Journal of Medicine., Vol.12, no.11,(2008), pp. 936-939.

[2] Alfredsson L and Kerlson EW, "Environmental Influence on Rheumatoid Arthritis", Current Opinion in Pharmacology., Vol.21, no.3, (2009),pp.270-283.

[3] Sakkas LI and Bodganos DP "Infections as a Cause of Autoimmune Rheumatic Disease: Autoimmune Highlights”. Vol.7, no.13,(2016),pp.2-8.

[4] Cojocaru L, Rusali AC, Cristina F, Mihaela A, Maria F and Craiu E "The Role of Simvastatin in 
the Therapeutic Approach of Rheumatoid Arthritis”, Journal of Autoimmune Disease., (2013),pp.1-8.

[5] Guo Q, Wang Y, Xu D, Nossent J, Pavlos NJ and Xu J, "Rheumatoid arthritis : pathological mechanisms and modern pharmacologic therapies",Bone Research., Vol.6, (2013),pp.1-14.

[6] Dhobale S, Narad V and Gaikwad D "Estimation of Lovastatin in Pharmaceutical Formulation by Area under Curve Spectrophotometric Method”, International journal of Applied Sciences., Vol.6, no.3, (2013), pp.85-93.

[7] Reddy VJS, Rao PGD and Lakshmi GR "A Review on Anti-Arthritic Activity of Some Medicinal Plants", Journal of Global Trends inPharmaceutical Sciences. Vol.5,no.4,(2014),pp-2061-2073.

[8] Vandebriel RJ, Jong HJI De, Gremmer ER, Klungel OH, Tervaert JC and Slob W "Statins accelerate the onset of collagen type II-induced arthritis in mice”, Arthritis Research Therapy [Internet]., Vol.14, no.2,(2012),pp.1-10.

[9] Kamanl A and Naz M "Plasma lipid peroxidation and antioxidant levels in patients with rheumatoid arthritis” Cell Biochemistry and Function., Vol.22,no.1,(2004),pp.53-57.

[10] Sarkar A, Vd Thripathi and Rk Saha "Anti-inflammatory and Anti-arthritis Activity of Flavonoids Fractions Isolated from Centipeda minima Leaves Extracts in Rats" Clinic Exp.Pharmacology., Vol.7, no.2,(2017),pp.1-8.

[11] Vijayakumar D, Suresh K and Manoharan S "Lipid Peroxidation and Antioxidant Status in Blood of Rheumatoid Arthritis”, Indian Journal of Clinical Biochemistry., Vol.21,no.1,(2006),pp.104-108.

[12] Husssain T, Shakla GS and Chandra SV "Effect of Cadmium on Superoxide Dismutase and Lipid Peroxidation in Liver and Kidney of Growing Rats: Invivo and Invitro Studies”, Pharmacology and Toxicology. Vol.60, no.5, (1987), pp.355-358. 